\title{
Shelter scaling regulates survival of juvenile Caribbean spiny lobster Panulirus argus
}

\author{
David B. Eggleston ${ }^{1,2}$, Romuald N. Lipcius ${ }^{1,2}$, David L. Miller ${ }^{3}$, Luis Coba-Cetina ${ }^{4}$ \\ ${ }^{1}$ The College of William and Mary, School of Marine Science, Virginia Institute of Marine Science, Gloucester Point, \\ Virginia 23062, USA* \\ ${ }^{2}$ Caribbean Marine Research Center, Lee Stocking Island, Exuma Cays, Bahamas \\ ${ }^{3}$ Department of Geography, State University of New York at Cortland, Cortland, New York 13045, USA \\ ${ }^{4}$ Centro de Investigaciones de Quintana Roo, Apartado Postal 424, Chetumal, Quintana Roo, Mexico
}

\begin{abstract}
Marine habitats with limited refugia from predation but adequate food may support increases in prey abundance if artificial shelters placed in these habitats reduce predation-induced mortality. Moreover, the protective capacity of shelters may vary according to the scaling between shelter size and prey size. We tested these hypotheses with field tethering experiments in Bahia de la Ascension, Mexico, by examining the impact of different-sized artificial shelters upon mortality rates of 3 juvenile size-classes of the Caribbean spiny lobster Panulirus argus at 2 sites (inner-bay sand-seagrass flat and outer-bay seagrass bed adjacent to coral reefs). The artificial shelters were sunken concrete structures (casitas) that simulate lobster dens. We also quantified potential predators and estimated the physical features of casitas that influence den choice by juvenile spiny lobster. In the tethering experiments, spiny lobster survival was (1) higher in casitas than seagrass meadows, irrespective of casita size; (2) generally higher in smaller than larger casitas, though the effect depended upon the relationship between lobster and shelter size; and (3) independent of site. Thus, spiny lobster survival depends not only upon the availability of shelter, but also on the scaling between shelter size and lobster size. Predator observations indicated that the size range, maximum size and species diversity of predators increased with casita size, thereby imposing higher predation intensity in larger casitas. Furthermore, since shelter appears to limit spiny lobster abundance in habitats such as reefs and seagrass meadows, placement of appropriately-scaled artificial shelters (e.g. casitas) in nursery areas like the study site is likely to augment habitat carrying capacity by increasing protection from predators.
\end{abstract}

\section{INTRODUCTION}

Habitat structural complexity affects predator-prey dynamics by providing refugia from predation (Gause 1934, Huffaker 1958, Smith 1972, Murdoch \& Oaten 1975). Reduced predator foraging efficiency in portions of a habitat may provide refugia that are partial (Huffaker 1958, Smith 1972) or absolute (Gause 1934). Recent experiments have emphasized structural complexity within habitats and its impact upon prey survival (Vince et al. 1976, Van Dolah 1978, Brock 1979 , Nelson 1979, Coen et al. 1981, Heck \& Thoman 1981, Crowder \& Cooper 1982, Peterson 1982, Coull \& Wells 1983, Ryer 1988, Gotceitas \& Colgan 1989). The general conclusion of these studies has been that increas-

\footnotetext{
${ }^{1}$ Address for correspondence
}

ing structural complexity (i.e. density or biomass of plants) decreases predator foraging efficiency. Whereas numerous investigators have examined different physical aspects of aquatic habitats providing structural complexity [e.g. submerged macrophytes (Crowder \& Cooper 1982, Coull \& Wells 1983), emergent macrophytes (Van Dolah 1978), worm tubes (Bell \& Coen 1982), and substrate type (Lipcius \& Hines 1986, Smith \& Coull 1987)], little work has focused on the effects of scaling of refugia according to prey size.

The geometry of natural surfaces suggests a scaled relationship between shelter dimensions and organism size, such that some specified scaling offers maximal protection to a sheltering individual (Morse et al. 1985, Caddy 1986). An obligate crevice dweller (e.g. spiny lobster, stomatopods, reef fish) is faced for all or part of its life history with a decline in the number of crevices as it grows (Caddy 1986, Moran \& Reaka 
1988), possibly leading to a population 'bottleneck' (Caddy 1986). Placement of artificial shelters at the appropriate scale could increase the effective number of crevices, thus alleviating the population bottleneck (Caddy 1986). However, a prerequisite to addressing sheiter-related bottlenecks is more detailed knowledge of how scaling of refuges affects size-specific survivorship.

Juveniles of the Caribbean spiny lobster Panulirus argus (Latreille) inhabitat shallow bays throughout the tropical and subtropical Western Atiantic. There they reside in crevices formed by rocky outcrops, coral reefs, sponges, solution holes, and undercut seagrass banks (Hermkind et al. 1975, Andree 1981, Marx \& Hermkind 1985, Herrnkind \& Lipcius in press). Juvenile P. argus are nocturnal predators that forage primarily on gastropods, crustaceans, pelecypods, and amphineurans (Lipcius \& Herrnkind 1982, Marx \& Herrnkind 1985). They reach carapace lengths of 60 to $70 \mathrm{~mm}$ after about 2 yr of benthic life (Sweat 1968). During the day they may aggregate in dens (Kanciruk 1980, Herrnkind \& Lipcius in press). Gregarious sheltering possibly enhances individual survivorship through communal defense (Berrill 1975, Cobb 1981, Zimmer-Faust \& Spanier 1987).

Intra- and interspecific aggression for suitable dens can force smaller juvenile Panulirus argus to find another den (Berrill 1975). Information on the physical properties that constitute a suitable den for $P$. argus is limited; however, den preferences of the California spiny lobster Panulirus interruptus include structures having shaded cover and multiple den openings (Spanier \& Zimmer-Faust 1988). Predation represents a major source of mortality for $P$. argus (Munro 1974, Herrnkind \& Butler 1986), and when individuals are displaced or forced to shelter in an inadequate den, they may be subject to increased predation rates (Herrnkind \& Butler 1986). Besides affording intermolt lobsters protection from predators and storm surge, dens provide refuge during molting (Lipcius \& Herrnkind 1982). Premolt individuals typically seek isolation during ecdysis, a period when they are extremely vulnerable to predation (Lipcius \& Hermkind 1982, D. B. Eggleston unpubl.).

Studies on recruitment and population dynamics indicate that habitat may be limiting for some

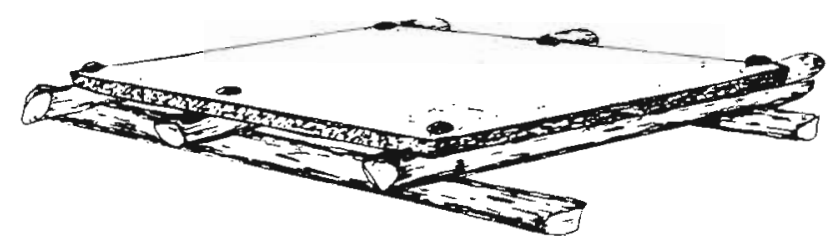

Fig. 1. A large 'casita' constructed with a frame of thatch palm and roof of cement palinurids. For example, recruitment of Panulirus cygnus in Western Australian waters is characterized by density-dependent mortality in nursery areas as a consequence of limitations in food or shelter (Chittleborough 1970, Chittleborough \& Phillips 1975, Ford et al. 1988). Thus, in areas of adequate food supply but limited shelter, placement of artificial lobster shelters of an appropriate design and size seems a feasible approach for augmenting habitat carrying capacity by increasing protection from predators. Yet, little information exists on the key biological and habitat variables useful in the design, construction, and placement of artificial lobster shelters, particularly with reference to protection from predators. Below we describe a series of field experiments which evaluate the efficacy of scaled artificial shelters in reducing size-specific mortality rates of juvenile Panulirus argus within 2 habitats. We also identify potential predators and estimate the physical features of the artificial shelters that influence den choice by juvenile $P$. argus in Bahia de la Ascension, Mexico.

\section{METHODS AND MATERIALS}

Shelter scaling. Our design of artificial lobster shelters was based on 'casitas' - sunken wood and concrete structures that simulate crevices in rocks and reefs (Miller 1982, 1989) (Fig. 1) and are used to concentrate lobsters for harvest in Cuba and the Mexican Caribbean (Miller 1982, 1989, Aguilar \& Gonzalez 1984, Cruz \& Brito 1986). Previous experiments in Bahia de la Ascension, Mexico indicate that casitas provide large juvenile lobsters greater protection from predators than seagrass habitats (Eggleston, Lipcius and Miller unpubl.). Thus, we hypothesized that scaling down the size of existing casitas would enhance the protective attributes of the casita for smaller lobsters (Fig. 1)

Our scaling of smaller casitas began with a reduction in the height of casita openings (Fig. 1). We assumed that existing large casitas (Fig, 1; $177 \mathrm{~cm}$ length $x$ $118 \mathrm{~cm}$ width $\times 6 \mathrm{~cm}$ height of opening) were suitable for concentrating large juveniles and adults $(>65 \mathrm{~mm}$ CL: carapace length) entering the fishery. We then assigned casita opening heights of $3.8 \mathrm{~cm}$ (medium casita) and $1.9 \mathrm{~cm}$ (small casita) to smaller casitas (mini-casitas) to correspond to medium 146 to $55 \mathrm{~mm}$ $\mathrm{CL}$ ) and small (35 to $45 \mathrm{~mm}$ CL) juveniles, respectively Reductions in casita opening height allowed for adequate entry of the targeted lobster size-class, but was also assumed to exclude larger predators.

Next we scaled the 'mini-casita' roofs according to reductions in casita height. A 2-dimensional scaling equation, $R=1 /(N)^{1 / 2}$ (Eq. 1) (Peitgen \& Saupe 1988), was employed to construct casita roofs that were identi- 
cally scaled. The value $\mathrm{N}$ was calculated by determining the ratio of large casita height to mini-casita height. For example, $\mathrm{N}$ for the medium casita was calculated as $6 \mathrm{~cm} / 3.8 \mathrm{~cm}=1.6$. $\mathrm{R}$ was then computed according to Eq. (1) $\left[R=1 /(1.6)^{1 / 2}\right]$ with the resulting scaling factor (R) multiplied by the area $\left(\mathrm{cm}^{2}\right)$ of the large casita roof [i.e. $\left.0.79 \times\left(177 \mathrm{~cm} \times 118 \mathrm{~cm}=16499.9 \mathrm{~cm}^{2}\right)\right]$. To determine the final length-width dimension of the mini-casita, a similarity ratio (Schmidt-Nielsen 1984) was calculated based on the ratio of corresponding sides of the large casita with Eqs. (2) and (3):

$$
\begin{aligned}
& \mathrm{K}_{1}=\mathrm{L}_{1} / \mathrm{L}_{2} \\
& \mathrm{~K}_{\mathrm{w}}=\mathrm{L}_{2} / \mathrm{L}_{1}
\end{aligned}
$$

where $K_{1}=$ the similarity ratio for length; $K_{w}=$ the similarity ratio for width; $\mathrm{L}_{1}=$ large casita length; and $\mathrm{L}_{2}=$ large casita width. This was then multiplied by the area of the mini-casita roof as determined from Eq. (1). For example, the length-width dimensions of the medium casita were determined as: $\mathrm{K}_{1}=177 / 118 \mathrm{~cm}=$ $1.5 \times 16499.9 \mathrm{~cm}^{2}=24749.9 \mathrm{~cm}^{2}$ and $\left(24749.9 \mathrm{~cm}^{2}\right)^{1 / 2}$ $=157.3 \mathrm{~cm}$. Similarly, $\mathrm{K}_{\mathrm{w}}=118 / 177 \mathrm{~cm}=0.67 \times$ $16499.9 \mathrm{~cm}^{2}=11054.9 \mathrm{~cm}^{2}$ and $\left(11054.9 \mathrm{~cm}^{2}\right)^{1 / 2}=$ $105.1 \mathrm{~cm}$. Thus, our calculations resulted in the construction of medium $(157.3 \times 105.1 \times 3.8 \mathrm{~cm})$ and small $(132.3 \times 88.4 \times 1.9 \mathrm{~cm})$ casitas. Shelters were constructed with a reinforced concrete roof connected to a PVC pipe frame with plastic cable-ties and wire.

Study site and tethering experiments. Tethering experiments were conducted in Bahia de la Ascension,

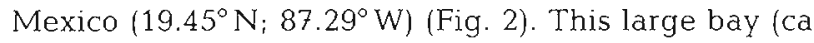
$260 \mathrm{~km}^{2}$ ) is an important nursery area for juvenile spiny lobsters and supports a commercial fishery for large

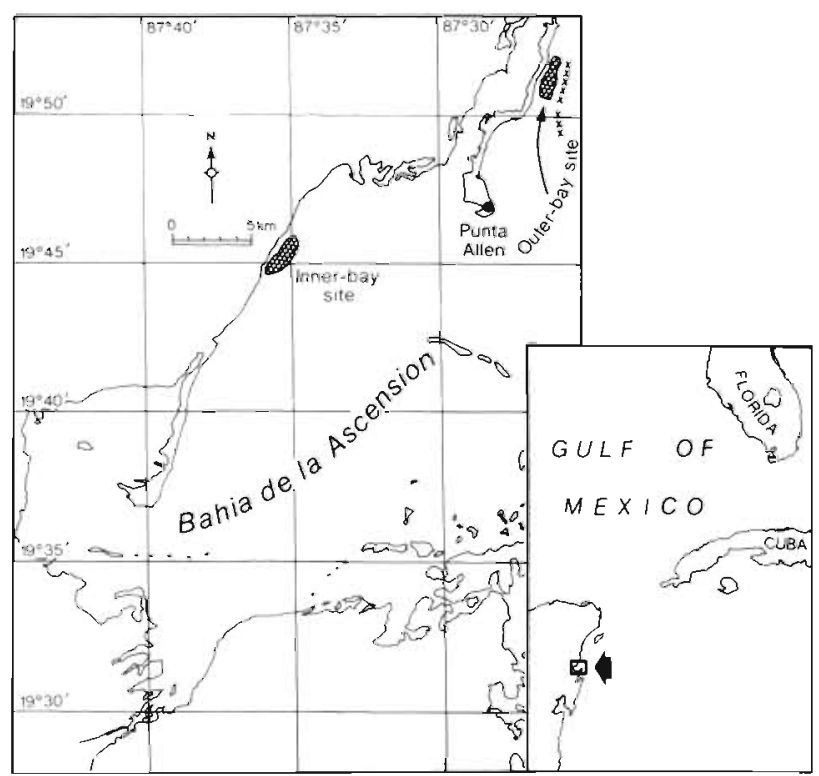

Fig. 2. Study sites at Bahia de la Ascension, Mexico juveniles and adults (Montes 1983, Miller 1989). Two experimental sites of contrasting habitat type were chosen to compare relative rates of predation: an innerbay sand-seagrass flat located at the northwest portion of the bay, and an outer-bay seagrass (Thalassia testudinum) meadow adjacent to a coral reef (Fig.2). Differences in density of seagrass between and within sites were determined at the beginning of the study by measuring dry weight biomass (g) of Thalassia removed from $0.25 \mathrm{~m}^{2}$ plots. Six samples were taken from 3 seagrass densities (dense, moderate, and sparse) and dry weights measured after drying at $100^{\circ} \mathrm{C}$ for $24 \mathrm{~h}$. The inner-bay site was composed of sparse seagrass patches $\left(\overline{\mathrm{x}}\right.$ Thalassia $=15.6 \mathrm{~g} 0.25 \mathrm{~m}^{-2}, \mathrm{SD}=$ 10.7) interspersed among coarse calcareous sand and coral rubble. The coral rubble was covered mostly by green and red algae (Dasycladus spp, and Laurencia spp., respectively), but also supported various sponges. The outer-bay site was located shoreward of a fringing coral reef and composed of sand patches and patch corals interspersed among moderate to dense seagrass beds $\left(\overline{\mathrm{x}}\right.$ Thalassia $=27.9 \mathrm{~g} 0.25 \mathrm{~m}^{-2}, \mathrm{SD}=13.4$ and $\overline{\mathrm{x}}$

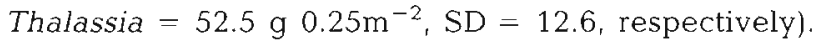
The seagrass beds are comparable in Thalassia biomass to other moderate-dense seagrass beds in the

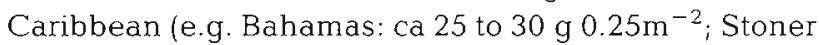
1989).

Spiny lobsters were collected from existing casitas and held in traps for 1 to $2 \mathrm{~d}$ prior to initiation of each experiment. Only intermolt lobsters were used in tethering experiments. Tethers were constructed by locking a plastic cable-tie around the cephalothorax of a lobster, between the second and third walking legs, and securing the cable-tie with cyanoacrylate cement. The cable-tie was connected with 30 -lb-test (14 kg) monifilament line either to another cable-tie and attached to a shelter, or attached to a J-shaped, stainless steel stake pushed into the sediment. The cyanoacrylate cement ensured that a piece of carapace remained on the line as evidence of predator-induced mortality (Herrnkind \& Butler 1986). Although tethering does not necessarily measure absolute rates of predation, it does measure relative rates of predation (Heck \& Thoman 1981), which can serve to compare mortality rates as a function of different experimental treatments.

Experimental design. Separate tethering experiments were performed during July and October 1988 and July 1989. In July 1988 we examined the survival of 2 sizes of juveniles in 2 casita sizes at the inner-bay nursery site. A row of large casitas was positioned ca $100 \mathrm{~m}$ from shore extending in an easterly direction towards the bay mouth (Fig. 2). Large casitas were placed 20 to $25 \mathrm{~m}$ apart; medium and small casitas were placed $10 \mathrm{~m}$ away from the large casitas. Each of 
6 stations consisted of the 3 casita sizes arranged in a triangular pattern. Juvenile lobsters were divided into 2 size-classes: medium ( 45 to $55 \mathrm{~mm} \mathrm{CL}$ ) and large (56 to $65 \mathrm{~mm} \mathrm{CL}$ ), and tethered for $7 \mathrm{~d}$ to large and medium casitas. Each large and medium casita had 6 tethered lobsters from either of the size classes giving a total of 72 tethered lobsters $(6$ lobsters $\times 6$ stations $\times 2$ casita sizes).

In October 1988, the previously described experiment was repeated at the inner-bay site, and an additional experiment was performed at the outer-bay reefseagrass site. The experiment at the outer-bay site used only medium-sized juveniles ( 56 to $65 \mathrm{~mm}$ CL) tethered to stakes either in dense seagrass without shelter or to large and medium casitas. Casitas were positioned equidistant between the shore and reef line and arranged in 2 rows, each containing 3 triangular stations. As above, the small casitas at each station were not used in these tethering experiments. Six lobsters were tethered to large and medium casitas at each station for $8 \mathrm{~d}$. Three additional stations were nonfunctional because of damage associated with Hurricane Gilbert. Lobsters in seagrass were tethered to single stakes arranged in the same order as the length-width dimensions of the large casita. The 3 seagrass stations without shelter were positioned $15 \mathrm{~m}$ away and perpendicular to the large casitas. Thus, in October we tethered 72 medium juvenile lobsters at the outer-bay site $[6$ lobsters $\times 3$ stations $\times(2$ casita sizes +2 seagrass sites), and 36 large and 36 medium juveniles at the inner-bay site $(6$ lobsters $\times 6$ stations $\times 2$ casita sizes)

In July 1989, we examined the survival of 2 size classes of juveniles in 3 casita sizes at the inner-bay site. Juvenile lobsters were classified as small (35 to $45 \mathrm{~mm} \mathrm{CL}$ ) or medium ( 46 to $55 \mathrm{~mm} \mathrm{CL}$ ) and tethered for $9 \mathrm{~d}$ at each of 6 stations containing small, medium, and large casitas. Each casita had 6 tethered lobsters of either size class, for a total of 108 lobsters ( 6 lobsters $x$ 6 stations $\times 3$ casita sizes).

To avoid tangling, tether lengths of 70,50 , and $30 \mathrm{~cm}$ were used with lobsters tethered to large, medium, and small casitas, respectively. Lobster size treatments were systematically interspersed between stations (sensu Hurlbert 1984), with 3 replicates for each lobster size and casita size combination.

Predation losses were scored and a visual census of potential predators taken every 1 to $2 \mathrm{~d}$ during experiments. Cumulative losses were converted to proportional mortality casita $\mathrm{d}^{-1}$. Proportions were analyzed as a function of shelter quality [casita size (large, medium, small) and no shelter], lobster size (large, medium, small), site (bay, reef), and date (July and October 1988) with 1-, 2-, and 3-way fixed-factor analyses of variance (ANOVA) models (after pro- cedures in Underwood 1981). Proportional mortality was arc-sine square-root transformed to meet assumptions of normality and homogeneity of variance (Underwood 1981). In all cases, either the variances were homogeneous as determined by Cochran's C-test, or the hypotheses were rejected at alpha values lower than the p-values of the test for homogeneity of variance (Underwood 1981). Differences among means were revealed by use of Student-Newman-Keuls (SNK) tests on the means (Underwood 1981).

During July and October 1988, the presence of potential lobster predators was only casually observed. In July 1989 we used a stationary visual census technique (Bohnsack \& Bannerot 1986) to quantify the community structure of potential predators associated with each of the 3 casita sizes during the experimental period. The visual census was usually performed between $10: 00$ and 14:00 h with 3 replicate samples taken during the experimental period. One night-time census was performed during the July 1989 experiment.

\section{RESULTS}

\section{Tethering experiments}

The inner-bay site was generally inhabited by small juvenile lobsters (30 to $80 \mathrm{~mm} \mathrm{CL;} \mathrm{Fig.} \mathrm{3a),} \mathrm{whereas} \mathrm{the}$ outer-bay site was inhabited by large juvenile and adult lobsters (60 to $100 \mathrm{~mm} \mathrm{CL;} \mathrm{Fig.} \mathrm{3b).} \mathrm{At} \mathrm{the} \mathrm{inner-}$ bay site during July and October 1988, casita and lobster size affected proportional mortality of juvenile spiny lobsters, with significantly lower mortality rates in medium casitas than large casitas, and for medium lobsters than large lobsters (Fig. 4; 3-way ANOVA; shelter size: $F=17.79$, df $=1,16, p<0.01$; lobster size: $\mathrm{F}=8.86, \mathrm{df}=1,16, \mathrm{p}<0.009$ ). Predation rates were not significantly affected by date (July vs October 1988), nor were there any interaction effects (Fig. 4; 3-way ANOVA, $p>0.1$ ).

At the outer-bay site in October 1988, mortality rates of medium juvenile lobsters were significantly affected by the presence or absence of artificial shelter (1-way ANOVA; $F=12.3, d f=2,8, p<0.008)$. Medium and large casitas provided significantly more protection from predation than seagrass (Fig. 5; SNK test, experimentwise error rate $=0.05$ ). During October 1988 predation rates on medium juvenile lobsters did not differ significantly between sites (inner-bay vs outer-bay: ANOVA, $F=4.72 ; \mathrm{df}=1.8 ; \mathrm{p}=0.328$ ).

Mortality rates of juvenile lobsters at the inner-bay site during July 1989 differed significantly by shelter size but not by lobster size (Table 1a). The interaction effect between shelter size and lobster size was significant (Table $1 \mathrm{a}$ ), precluding contrasts among treatment 
A

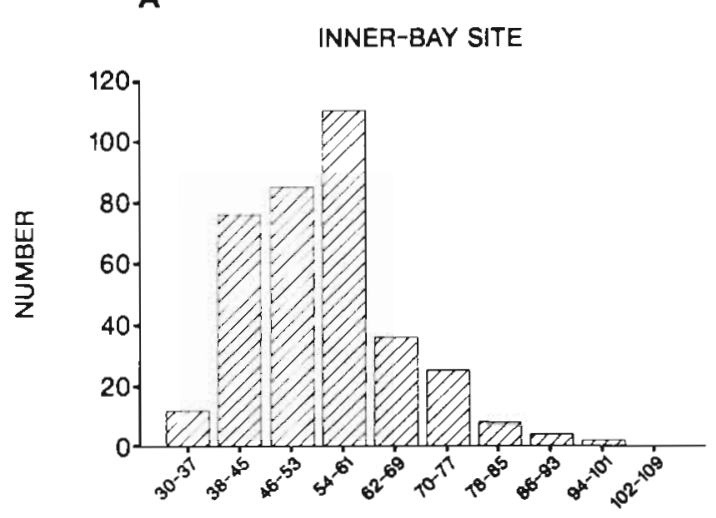

B

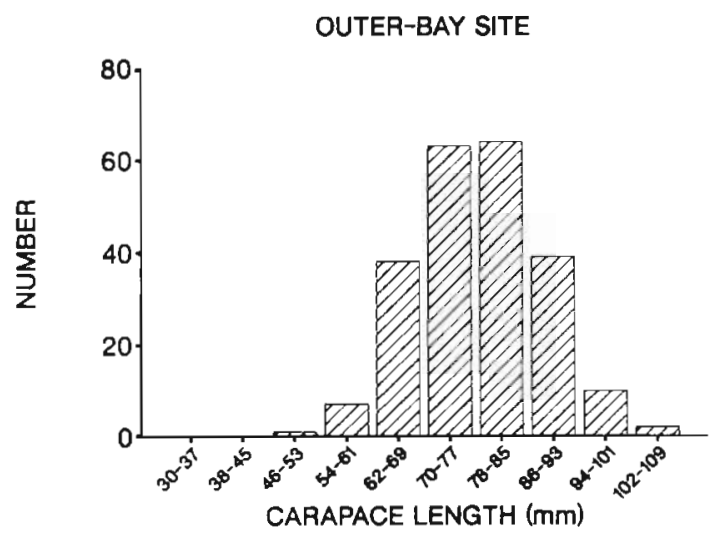

Fig. 3. Panulirus argus. Size-frequency of lobsters captured from large casitas at the 2 field sites. (A) Inner-bay site; mean $=53.9 \mathrm{~mm} \mathrm{CL}$, range $=31$ to $100 \mathrm{~mm} \mathrm{CL}$ (15 casitas sampled). (B) Outer-bay site; mean $=77.8 \mathrm{~mm} \mathrm{CL}$, range $=47$ to $118 \mathrm{~mm}$ CL (20 casitas sampled)

means (Underwood 1981). Thus, we examined treatment effects within each lobster and shelter size. The interaction effect was due to mortality differences between casita sizes within each lobster size class. Small lobsters had significantly higher survivorship in small shelters followed in decreasing order by medium and large shelters (Fig. 6; Table 1b). Although medium shelters afforded more protection to medium lobsters than either large or small shelters (Fig. 6), as in the previous experiments (Figs. 4 and 5), the trend was not significant (Table 1b).

\section{Predator observations}

Casitas also attracted or concentrated numerous reef fish, especially at the inner-bay site. Potential piscine predators of juvenile lobsters at the inner-bay site during July and October 1988 included gray snapper Lutjanus griseus, schoolmaster snapper L. apodus, mutton snapper L. analis, barracuda Sphyraena barracuda,

\section{JULY-1988}

BAY SITE

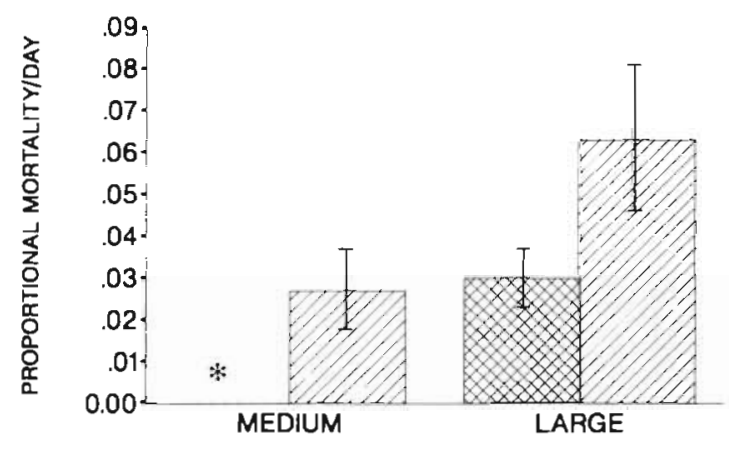

OCTOBER-1988
BAY SITE

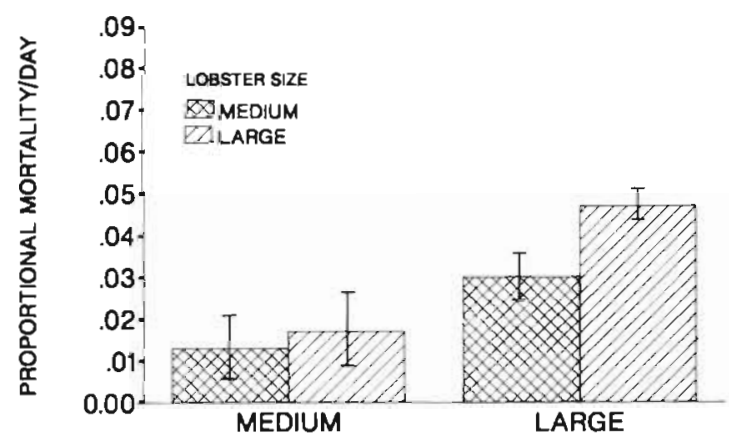

SHELTER SIZE

Fig. 4. Panulirus argus. Results of field tethering experiments at the inner-bay nursery site comparing predation as a function of juvenile lobster size (medium: 46 to $55 \mathrm{~mm} \mathrm{CL}$ and large: 56 to $65 \mathrm{~mm} \mathrm{CL)}$, shelter size (medium and large), and date (July and October 1988). Values are mean proportional mortality casita ${ }^{-1} \mathrm{~d}^{-1}$ Vertical bars are $1 \mathrm{SE}$. "No mortalities observed

\section{OCTOBER-1988}

REEF SITE

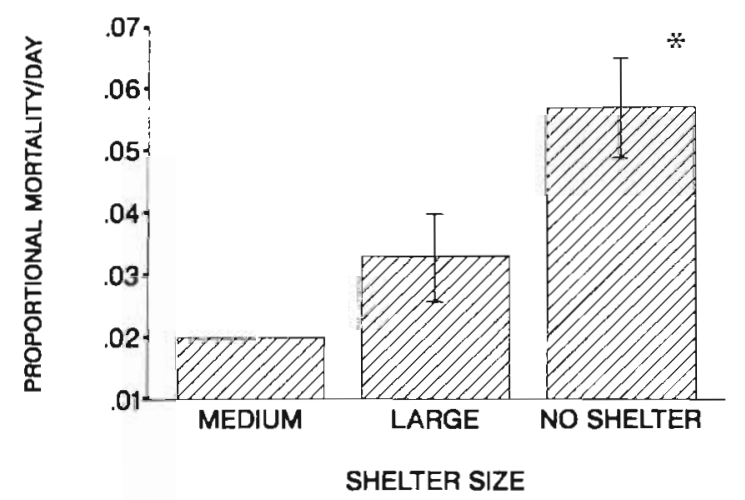

Fig. 5. Panulirus argus. Results of field tethering experiments at the outer-bay seagrass site with medium juveniles (46 to $55 \mathrm{~mm} \mathrm{CLl,} \mathrm{comparing} \mathrm{predation} \mathrm{in} \mathrm{medium} \mathrm{and} \mathrm{large} \mathrm{size}$ shelters, and without shelter. Values are mean proportional mortality station ${ }^{-1} \mathrm{~d}^{-1}$. Vertical bars are $1 \mathrm{SE}$. 'Significantly different, $p<0.05$ 
JULY-1989

BAY SITE

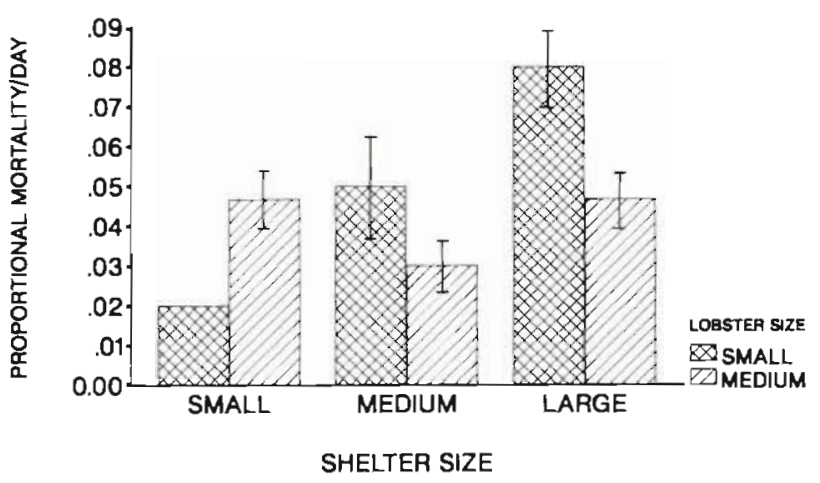

Fig. 6. Results of field tethering experiments at the inner-bay nursery site during July 1989 comparing predation as a function of juvenile lobster size (small: 35 to $45 \mathrm{~mm} \mathrm{CL}$ and medium: 46 to $55 \mathrm{~mm} \mathrm{CL}$ ) and shelter size (small, medium, and large). Values are mean proportional mortality casita $^{-1} d^{-1}$. Vertical bars are $1 \mathrm{SE}$

green moray eel Gymnothorax funebris, nurse shark Ginglyostoma cirratum and bottlenose dolphin Tursiops truncatus. Other potential predators at the innerbay site included the loggerhead turtle Caretta caretta, stone crab Menippe mercenaria and portunid crabs. Potential predators at the outer-bay site included mutton snapper, yellowtail snapper Ocyurus chrysurus,

Table 1. (a) Two-way analysis of variance of arc-sine squareroot transformed proportional mortality rates (proportional mortality casita ${ }^{-1} \mathrm{~d}^{-1}$ ) at the inner-bay nursery site during July 1989, examining the effects of shelter size (small, medium, large) and lobster size (small and medium)

\begin{tabular}{|lrrrr|}
\hline Experimental condition & df & MS & F & $p<$ \\
\hline Shelter size & 2 & 0.008 & 9.20 & 0.004 \\
Lobster size & 1 & 0.001 & 1.07 & 0.321 \\
Shelter size $\times$ lobster size & 2 & 0.009 & 10.04 & 0.003 \\
Error & 12 & 0.001 & & \\
\hline
\end{tabular}

gray snapper, barracuda, green moray eel, spotted moray eel Gymnothorax moringa, and octopus. The visual census of potential predators at the inner-bay site during July 1989 indicated that total abundance, mean number of individuals per casita per sample, and mean length increased with casita size (Table 2). Large casitas concentrated more species of potential predators followed in decreasing order by medium and small casitas (Table 2). Gray snapper was the predominant potential predator, irrespective of casita size (Table 2). The night-time visual census indicated that the predator guild observed during the day had dispersed within 1 h after dusk.

\section{DISCUSSION}

Seagrass meadows provide refuge for small decapods, reduce predation risk, and thereby enhance survival of spiny lobsters (Herrnkind \& Butler 1986 , Lipcius, Eggleston, Miller and Camarena unpubl.) and crabs (Heck \& Thoman 1981, Heck \& Wilson 1987). Results from our outer-bay experiment in October suggest that shelter is limited in seagrass meadows and that placement of casitas in these habitats enhances survivorship of juvenile Panulirus argus. Placement of casitas in seagrass meadows also places suitable shelter near foraging grounds, and thereby reduces energetic demands associated with movements between sheltering and feeding grounds. Such close coupling of adjacent habitats has been documented between coral reefs and seagrass beds. Reef fish such as grunts, snappers, squirrelfishes Holocentrus spp. and cardinalfishes Apogon spp. move between diurnal shelter sites on coral reefs and nocturnal feeding grounds in seagrass meadows (Starck \& Davis 1966, Ogden \& Ziemann 1977, Robblee \& Zieman 1984). Ogden \& Ziemann (1977) found that the interconnection between these 2 habitats increased fish biomass on reefs.

Table 1 (b) SNK tests of mean arc-sine square-root transformed proportional mortality rates of lobsters for the shelter size $x$ lobster size interaction effect

\begin{tabular}{|c|c|c|c|c|c|c|}
\hline \multicolumn{7}{|l|}{ Treatments } \\
\hline Lobster size: & Small & Small & Small & Medium & Medium & Medium \\
\hline \multirow[t]{2}{*}{ Shelter size: } & Small & Medium & Large & Small & Medium & Large \\
\hline & L & $\cdots$ & 1 & & All NS & \\
\hline
\end{tabular}


Table 2. Summary of results from visual census of potential lobster predators associated with 18 casitas of 3 sizes (small, medium, large) during 22 to 31 July 1989. Results below are pooled from censusing 18 casitas on 3 different sampling dates. Fish size is fork length $(\mathrm{cm})$ and crab size is carapace width $(\mathrm{cm})$

\begin{tabular}{|c|c|c|c|c|c|c|c|}
\hline \multirow[t]{2}{*}{ Species } & \multirow{2}{*}{$\begin{array}{c}\text { Total } \\
\text { abundance }\end{array}$} & \multirow{2}{*}{$\begin{array}{l}\text { Mean no. } \\
\text { ind. } \\
\text { sample } \\
\text { casita }^{-1}\end{array}$} & \multirow{2}{*}{$\begin{array}{c}\text { Frequency } \\
\text { per casita } \\
(\mathrm{N}=18)\end{array}$} & \multirow{2}{*}{$\begin{array}{l}\text { Percent } \\
\text { frequency }\end{array}$} & \multicolumn{3}{|c|}{ Size $(\mathrm{cm})$} \\
\hline & & & & & Mean & Min. & Max. \\
\hline \multicolumn{8}{|l|}{ Large casita: } \\
\hline Lutjanus griseus (gray snapper) & 222 & 12.33 & 18 & 100.0 & 20.4 & 10 & 35 \\
\hline Lutjanus apodus (schoolmaster snapper) & 64 & 3.56 & 11 & 61.1 & 18.1 & 10 & 25 \\
\hline Lutjanus analis (mutton snapper) & 10 & 0.56 & 6 & 33.3 & 20.3 & 15 & 30 \\
\hline Sphyraena barracuda (great barracuda) & 3 & 0.17 & 3 & 16.7 & 103.3 & 90 & 120 \\
\hline Epinephelus striatus (Nassau grouper) & 1 & 0.06 & 1 & 5.6 & 45.0 & - & - \\
\hline Epinephelus guttatus (red hind) & 1 & 0.06 & 1 & 5.6 & 12.0 & - & - \\
\hline Dasyatis americana (southern stingray) & 1 & 0.06 & 1 & 5.6 & $50.0^{\bullet}$ & - & - \\
\hline \multicolumn{8}{|l|}{ Medium casita: } \\
\hline Lutjanus griseus (gray snapper) & 79 & 4.39 & 11 & 61.1 & 12.7 & 7 & 15 \\
\hline Lutjanus analis (mutton snapper) & 8 & 0.44 & 5 & 27.8 & 15.8 & 10 & 20 \\
\hline Lutjanus apodus (schoolmaster snapper) & 7 & 0.39 & 3 & 16.7 & 12.5 & 10 & 18 \\
\hline Menippe mercenaria (stone crab) & 3 & 0.17 & 3 & 16.7 & 10.0 & 10 & 10 \\
\hline Portunus spinimanus (portunid crab) & 2 & 0.11 & 2 & 11.1 & 9.5 & 6 & 13 \\
\hline \multicolumn{8}{|l|}{ Small casita: } \\
\hline Lutjanus griseus (gray snapper) & 12 & 0.67 & 5 & 27.8 & 7.6 & 6 & 10 \\
\hline Lutjanus apodus (schoolmaster snapper) & 2 & 0.11 & 1 & 5.6 & 7.0 & - & - \\
\hline Portunus spinimanus (portunid crab) & 5 & 0.28 & 3 & 16.7 & 8.5 & 7 & 12 \\
\hline Menippe mercenaria (stone crab) & 1 & 0.06 & 1 & 5.6 & 6.0 & - & - \\
\hline
\end{tabular}

Our field experiments further demonstrate that scaling of refuges according to prey size enhances prey survivorship by providing protection from predators The likely mechanism producing this pattern is a reduction in accessibility of piscine predators to lobsters in low shelters. These results imply that limitations to the distribution and abundance of spiny lobsters within shelters are a consequence of complex interactions involving lobster density, and the sizes of lobster, shelter, and predator. For instance, the maximum size of a lobster within a particular shelter is limited by the size of the shelter, whereas the minimum size is limited by shelter-associated predators. This relationship is further complicated by (1) social dominance within a shelter, whereby small lobsters may be forced out, or (2) gregarious behavior that might enhance the lower size range of lobsters that can survive.

Survival of small ( 35 to $45 \mathrm{~mm} \mathrm{CL}$ ) and medium (46 to $55 \mathrm{~mm} \mathrm{CL}$ ) lobsters was generally dependent on casita size - small and medium casitas afforded the best protection to small and medium lobsters, respectively. Survival of large juveniles (56 to $65 \mathrm{~mm}$ CL) did not always depend on shelter size. For instance, large lobsters had higher survivorship in medium casitas than in large casitas, and medium lobsters demonstrated higher survivorship in large casitas than did large lob- sters. The increased survivorship of large juvenile lobsters in medium casitas compared to large casitas indicates that medium casitas eliminate predators that are able to prey on large juvenile lobsters. Differential survivorship of medium and large juvenile lobsters in large casitas could be a consequence of variations in predator and prey size. The predator observations indicated that a characteristic suite of predator sizes corresponded to each casita size, with large casitas concentrating larger adult fish. Adult fish may become more selective because of better visual perception with age (i.e. size) (Kao et al. 1985), and predator discrimination may become more acute with increasing prey size (Stein 1977). However, more information is needed on the mechanisms of predator choice in this system to discern the precise role of variation in predator and prey sizes in regulating prey survival.

The allometry of predator vulnerability with shelter and body size is fundamental in predicting size-specific asymmetries in species interactions or ontogenetic niche shifts (Werner \& Gilliam 1984). Thus, the use of appropriately scaled casitas might be used to examine shelter-related population bottlenecks (sensu Caddy 1986) for juvenile Panulirus argus. In a somewhat analogous study, Reise (1978) examined how mesh size of predator exclusion cages provided differential pro- 
tection to infaunal prey. Cages with 5, 2, and $1 \mathrm{~mm}$ mesh enhanced macrofaunal survival (sieved through a $0.25 \mathrm{~mm}$ mesh) by excluding crabs, shrimp, and gobiid fish, whereas cages with $20 \mathrm{~mm}$ mesh did not (Reise 1978). Another possible analogue to our findings may be the use of reef cavities as refuges for reef-dwelling stomatopods. Abundance of stomatopod crustaceans in subtidal reef populations is affected by predation (Reaka 1985), such that the sizes of available reef cavities may limit the body sizes of these stomatopods (Moran \& Reaka 1988). Thus, the introduction of artificial reef cavities of the appropriate scale (sensu Caddy 1986) might also be a productive approach for examining shelter-related population bottlenecks of stomatopods and other reef-dwelling species.

The placement of casitas throughout Bahia de la Ascension provides juvenile spiny lobsters with additional, more effective shelter from predators. Various shelter features may be important in reducing predation. For instance, shaded cover provided by dens may decrease encounters with visually directed predators (Spanier \& Zimmer-Faust 1988), which for Panulirus argus are principally diurnally active fishes (Cruz \& Brito 1986, Hermkind \& Butler 1986). However, further experiments are needed to determine differences in the impact of casitas upon lobster survival in the day and night.

Key physical properties of the casita that likely influence den choice and increase survivorship of juvenile Panulirus argus are (1) a shaded cover provided by the wide concrete roof, (2) low roof height, which excludes large piscine predators, and (3) multiple den openings that are smaller than the inner roof height of the casita. Recruitment of the slipper lobster Scyllarides latus to artificial reefs of different design indicated a preference for lower, horizontal dens with small openings (Spanier et al. 1988). Field surveys in California indicated that dens occupied by Panulirus interruptus usually had more than one entrance and that entrances were much smaller than the inner diameter of a den (Spanier \& Zimmer-Faust 1988). Furthermore, den preferences of $P$. interruptus depended more on the presence of shaded cover than on den walls, with single. isolated dens having front and rear entrances being selected over dens with only one entrance (Spanier \& Zimmer-Faust 1988). Multiple den openings provide alternate escape routes, and may facilitate social grouping with collective anti-predator vigilance. We commonly observed groups of lobsters with their antennae protruding from each opening of a casita, somewhat resembling a defensive pod (Kanciruk 1980) with a roof over it.

The collective evidence from field observations and experiments suggests that shelter is limiting spiny lobster abundance in certain habitats such as reefs (Ford et al. 1988) and seagrass meadows (this study), with a dynamic interplay between shelter and food availability (Herrnkind 1980). Thus, the placement of appropriately-scaled casitas, which are inexpensive and extremely durable as evidenced by our low loss rate $(8 \%)$ of structures in the direct path of Hurricane Gilbert (D. B. Eggleston unpubl.), may be an economical and effective approach for increasing fisheries production in the Caribbean by increasing protection from predators. However, final conclusions regarding the impact of artificial shelters on spiny lobster predatorprey dynamics and production in nursery areas warrant field manipulations that test the aforementioned hypotheses.

Acknowledgements. We thank T Camarena and E. Cordero with the Centro de Investigaciones de Quintana Roo, and numerous Earthwatch volunteers, for their able field assistance. Thanks to J. Eggleston for drawing the figure of the casita. Special thanks to Armando Lopez and Sonja Lillvick for the fine accomodations and logistical support. We thank $M$. Butler, W. Herrnkind, C. Peterson and 2 anonymous referees for critical comments. This work was funded by Sigma-Xi, Earthwatch-The Center for Field Research, the National Undersea Research Program of the National Oceanic and Atmospheric Administration, the Caribbean Marine Research Center, and the National Science Foundation (INT-8617945 to D. M. and R. L. and OCE-87004414 to R. L. and A. Hines) Contribution No. 1579 from the Virginia Institute of Marine Science.

\section{LITERATURE CITED}

Aguilar, C., Gonzalez, G. (1984). Primeras etapes en la colonizacion de refugios artificiales. II. Tasas de colonizacion. Rev. Inv. Mar. 5: 91-98

Andree, S. (1981). Locomotory activity patterns and food items of benthic postlarval spiny lobsters, Panulirus argus. M. S. thesis, Florida State University, Tallahasee

Bell, S. S., Coen, L. D. (1982). Investigations on epibenthic meiofauna. II. Influence of microhabitat and macroalgae on the abundance of small invertebrates on Diopatra cuprea [(Bosc) (Polychaeta: Onuphidae)] tube caps in Virginia. J. exp mar. Biol. Ecol. 61: 175-188

Berrill, M. (1975). Gregarious behavior of juveniles of the spiny lobster, Panulirus argus (Crustacea: Decapoda). Bull. mar Sci 2.5: 515-522

Bohnsack, J. A., Bannerot, S. P. (1986). A stationary visual census technique for quantitatively assessing community stricture of coral reef fishes. NOAA Tech. Rep. NMFS 41 , p. $1-15$

Brock, R. E. (1979). An experimental study on the effects of grazing by parrotfishes and role of refuges in benthic community structure. Mar. Biol. 51 381-388

Caddy, J. F. (1986). Modelling stock-recruitment processes in Crustacea: some practical and theoretical perspectives. Can. J. Fish. Aquat Sci. 43: 2330-2344

Chittleborough, R. G. (1970). Studies on recrutment in the Western Australian Rock lobster, Panulirus longipes cygnus: density and natural mortality of juveniles. Aust. J. mar. Freshwat. Res. 21 (2): 131-148

Chittleborough, R. G., Phillips, B. F. (1975). Fluctuations of 
year-class strength and recruitment in the western rock lobster, Panulirus longipes (Milne-Edwards). Aust. J. mar Freshwat. Res. 26: 317-328

Cobb, J. S. (1981). Behaviour of the Western Australian spiny lobster, Panulirus cygnus George, in the field and laboratory. Aust. J. mar. Freshwat. Res. 31: 399-409

Coen, L. D., Heck, K. L. Jr, Abele, L. G. (1981). Experiments on competition and predation among shrimps of seagrass meadows. Ecology 62: 1484-1493

Coull, B. C., Wells, J. B. J. (1983). Refuges from fish predation: experiments with phytal meiofauna from the New Zealand rocky intertidal. Ecology 64: 1599-1609

Crowder, L. B., Cooper, W. E. (1982). Habitat structural complexity and the interaction between bluegills and their prey. Ecology 63: 1802-1813

Cruz, R., Brito, R. (1986). Ecologia de la langosta (Panulirus argus) al SE de Isla de la Juventud. I. Colonizacion de arrecifes artificiales. Rev. Inv. mar. 7: 3-17

Ford, R. F., Phillips, B. F., Joll, L. M. (1988). Experimental manipulation of population density and its effects on growth and mortality of juvenile western rock lobsters, Panulirus cygnus George. Fish. Bull. U.S. 86: 773-787

Gause, G. F. (1934). The struggle for existence. Hafner, New York

Gotceitas, V., Colgan, P. (1989). Predator foraging success and habitat complexity: quantitative test of the threshold hypothesis. Oecologia (Berl.) 80: 158-166

Heck, K. L. Jr, Thoman, T. A. (1981). Experiments on predatorprey interactions in vegetated aquatic habitats. J. exp. mar. Biol. Ecol. 53: 125-134

Heck, K. L. Jr, Wilson, K. A. (1987). Predation rates on decapod crustaceans in latitudinally separated seagrass communities: a study of spatial and temporal variation using tethering techniques. J. exp. mar. Biol. Ecol. 107 : $87-100$

Herrnkind, W F. (1980). Spiny lobsters: patterns of movement. In: Cobb, J. S., Phillips, B. F. (eds.) The biology and management of lobsters, Vol. I, Physiology and behavior. Academic Press, New York, p. 349-407

Herrnkind, W. F., Vanderwalker, J., Barr, L. (1975). Population dynamics, ecology and behavior of spiny lobsters, Panulirus argus, of St. John, U.S. Virgin Islands: habitation and pattern of movements. Sci. Bull. nat. Hist. Mus. Los Ang. Cty 20: 31-34

Herrnkind, W. F., Butler, M. J. (1986). Factors regulating postlarval settlement and juvenile microhabitat use by spiny lobsters Panulirus argus. Mar Ecol Prog. Ser. 34: 23-30

Herrnkind, W. F., Lipcius, R. N. (in press). Habitat use and population biology of Bahamian spiny lobster. Proc. Gulf Caribb. Fish. Inst. 39

Huffaker, C. B. (1958). Experimental studies on predation: dispersion factors and predator-prey oscillations. Hilgardia 27: $343-383$

Hurlbert, S. (1984). Pseudoreplication and the design of ecological field experiments. Ecol. Monogr. 54: 187-211

Kanciruk, P. (1980). Ecology of juvenile and adult Palinuridae (spiny lobsters). In: Cobb, J. S., Phillips, B. F. (eds.) The biology and management of lobsters, Vol. 2, Ecology and management. Academic Press, New York, p. 59-96

Kao, T., Wetterer, J. K., Hairston, N. G., Jr (1985). Fish size, visual resolution and prey selectivity. Ecology 66: $1729-1735$

Lipcius, R. N., Herrnkind, W. F. (1982). Molt cycle alterations in behavior, feeding and diel rhythms of a decapod crustacean, the spiny lobster Panulirus argus. Mar. Biol. 68: $241-252$

Lipcius, R. N., Hines, A. H. (1986). Variable functional respon- ses of a marine predator in dissimilar homogeneous microhabitats. Ecology 67: 1261-1371

Marx, J. M., Herrnkind, W. F. (1985). Macroalgae (Rhodophyta: Laurencia spp.) as habitat for young juvenile spiny lobsters, Panulirus argus. Bull. mar Sci 36: 423-431

Miller, D. L. (1982). Construction of shallow water habitats to increase lobster production in Mexico. Proc. Gulf Caribb. Fish. Inst. 34: 168-179

Miller, D. L. (1989). Technology, territoriality and ecology: the evolution of Mexico's Caribbean spiny lobster fishery. In: Barkes, F. (ed.) Common property resources: ecology and community-based sustainable development. Valhaven Press, London, p. 185-198

Montes, J. J. E. (1983). Biologia aquatica descripcion general de los recursos bioticos y economicos. In: Careaga, A. (ed.) Sian Ka'an: estudios preliminares de una zona en Quintana Roo propuesta como reserva de la biosfera. Litoarte, Mexico, D. F, p. 193-215

Moran, D. P., Reaka, M. L. (1988). Bioerosion and availability of shelter for benthic reef organisms. Mar. Ecol. Prog. Ser. 44: 249-263

Morse, D. R., Lawson, J. H., Dodson, M. M., Williamson, M. H. (1985). Fractal dimension of vegetation and the distribution of arthropod body lengths. Nature, Lond. 314: 731-733

Munro, $T$ (1974). The biology, ecology, and bionomics of Caribbean reef fishes. Part VI. Crustaceans (spiny lobsters and crabs). Res. Rep. Zool. Dept Univ. W. Indies 3: 1-57

Murdoch, W. W. Oaten, A. (1975). Predation and population stability. Adv. ecol. Res. 9: 2-131

Nelson, W. G. (1979). Experimental studies of selective predation on amphipods: consequences for amphipod distribution and abundance. J. exp. mar. Biol. Ecol. 38: 225-245

Ogden, J. C., Ziemann, J. C. (1977). Ecological aspects of coral-reef seagrass bed contacts in the Caribbean. Proc. Third Int. Coral Reef Congr. 1: 377-382

Peitgen, H., Saupe, D. (1988). The science of fractal images. Springer-Verlag Inc., New York

Peterson, C. H. (1982). Clam predation by whelks (Busycon $\mathrm{sp}$.): experimental tests of the importance of prey size, prey density, and seagrass cover. Mar. Biol. 66: 159-170

Reaka, M. L. (1985). Interactions between fishes and motile benthic invertebrates on reefs: the significance of motility vs. defensive adaptations. Proc. Fifth Int. Coral Reef Congr. 5: 439-444

Reise, K. (1978). Experiments on epibenthic predation in the Wadden Sea. Helgoländer Wiss. Meeresunters. 31: 55-101

Roblee, M. B., Ziemann, J. C. (1984). Diel variation in the fish fauna of a tropical seagrass feeding ground. Bull. mar. Sci. $34: 335-345$

Ryer, C. H. (1988). Pipefish foraging: effects of fish size, prey size and altered habitat complexity. J. exp. mar. Biol. Ecol. 48: $37-45$

Schmidt-Nielsen, K. (1984). Scaling: why is animal size so important? Cambridge University Press, Cambridge

Smith, F. E. (1972). Spatial heterogeneity, stability and diversity in ecosystems. Trans. Conn. Acad. Arts Sci. 44: 309-335

Smith, L. D., Coull, B. C. (1987). Juvenile spot (Pisces) and grass shrimp predation on meiobenthos in muddy and sandy substrata. J. exp. mar. Biol. Ecol. 105: 123-136

Spanier, E., Tom, M., Pisanty, S., Almog, G. (1988). Seasonality and shelter selection by the slipper lobster, Scyllarides latus ni the southeastern Mediterranean. Mar. Ecol. Prog. Ser. 42: $247-255$

Spanier, E., Zimmer-Faust, R. K. (1988). Some physical properties of shelter that influence den preference in spiny lobsters. J. exp. mar. Biol. Ecol. 121: 137-149 
Starck, W. A. II., Davis, W P. (1966). Night habitats of fishes on Alligator Reef, Florida. Ichthyologica 38: 313-355

Stein, R. A. (1977). Selective predation, optimal foraging and the predator-prey interaction between fish and crayfish Ecology 58: 1227-1235

Stoner, A. W. (1989). Density-dependent growth and grazing effects of juvenile queen conch, Strombus gigas L., in a tropical seagrass meadow. J. exp. mar. Biol. Ecol. 130: 119-133

Sweat, D. E. (1968). Growth and tagging studies on Panulirus argus (Latreille) in the Florida Keys. Tech. Ser Fla. St. Bd Conserv. 57: 1-30

Underwood, A. (1981). Techniques of analysis of variance in experimental marine biology and ecology. Oceanogr. mar. Biol. A. Rev. 19: 513-605

This article was presented by Professor C. H. Peterson, Morehead City, N. Carolina, USA
Van Dolah, R. F. (1978). Factors regulating the distribution and population dynamics of the amphipod Gammarus palustris in an intertidal salt marsh community. Ecol. Monogr. 48: 191-217

Vince, S., Valiela, I., Backus, N., Teal, J. M. (1976). Predation by the salt marsh killifish Fundulus heteroclitus (L.) in relation to prey size and habitat structure: consequences for prey distribution and abundance. J. exp. mar Biol. Ecol. 23: 255-266

Werner, E. E., Gilliam, J. F. (1984). The ontogenetic niche and species interactions in size-structured populations. Ann. Rev. Ecol. Syst. 15: 393-425

Zimmer-Faust, R. K., Spanier, E. (1987). Gregariousness and sociality in spiny lobsters: implications for den habitation. J. exp. mar. Biol. Ecol. 105: 57-71

Manuscript first received: May 2, 1989

Revised version accepted: January 12, 1990 